Road Bowling in Ireland: Social Space and the Context of Context 


\begin{abstract}
Consumer research has offered a multitude of understandings of space. While these insights have contributed both to absolute and relativistic appreciations, the discourse has tended more often towards absolute representations. Through an examination of Irish road bowling, built from a four year ethnography, we position Henri Lefebvre's triadic model of social space as a heuristic device that may be used to further relativistic representations of space. In doing so we expose how Irish road bowlers produce space on public roads. We find that such space and the actions of road bowlers within it are deeply influenced by both historic and contemporary socio-cultural discourses. In this way we highlight how Lefebvre can be used to get at the context of context and offer an alternative understanding of normative and existential communitas.
\end{abstract}

Keywords: Irish road bowling, Lefebvre, space, transitory dwelling places, communitas. 


\section{Road Bowling In Ireland: Social Space and the Context of Context}

Oh **** what's happening? I saw Teddy hurtling towards me. He was running, leaping up and down, shouting at the top of his voice. Like a monkey set free from captivity, racing away from his captors, limbs flailing in the air, roaring in ecstasy. Others similarly buzzed past me. I actually didn't have the greatest view of the shot. I saw it pass and then it disappeared. The funnel of the crowd split as the bowl passed them by. For a moment there was silence. Then echoes towards the front of the crowd. Then jumping further down the road, as they realized just how long the throw was. Cue the release. I'm off like a mad man down the road hugging all the lads, bellowing at the top of my voice. "Doubt ya Driscoll Boy!" "That's a desperate iron." "You can't beat the ticker kid!" Familiar sayings echo about the place as we celebrate on the road. For a full five minutes we were a pack of wild beasts feasting.

Ethnographic Fieldnotes

Road bowling is a traditional sport played in small pockets of the Irish countryside. As the name suggests, it involves bowling on a road; that is, throwing a small metal ball that weighs $28 \mathrm{oz}$ along a public road. There is a start line and a finish line, and the game operates on roughly the same premise as golf in that the player to reach the finish line in the least number of throws wins. Each game is called a scór - a Gaelic term to denote twenty throws, a legacy from days gone by when matches were regularized to twenty bowls (Toal 1996). Scórs take place on public roads and are organized by various road bowling clubs in specific localities. While scórs are in action, traffic considerations become secondary. In fact, passing traffic is often brought to a complete stop and commuters must wait for road bowlers to allow them to pass. Lane $(2005,6)$ captures the essence of this scene:

"Motorists moving throughout the countryside occasionally come across crowds of people on roads engaged with a game of road bowling, hundreds of spectators leisurely walking the road ... For many that are unaccustomed to these scenes, it must appear an unusual and even archaic sport, a throwback to the days when roads were not monopolized by fast moving traffic."

(Insert figure 1) 
The scene that Lane describes is commonplace on the roads of Ireland, particularly in counties Cork and Armagh where road bowling is most prominent. ${ }^{1}$ The appropriation of space involved here is interesting. Roads in Ireland, like any country, are integral to the growth of economic and market systems (Flower 2004), they play host to a range of commercial buildings including petrol stations, motels, drive-ins and drive-thrus (Sheller and Urry 2003; Newman 2016), and they require almost constant maintenance from council officials and road crews (Goodwin 2010): "they could arguably be taken as the paradigmatic material infrastructure of the twenty-first century, supporting both the information society (in the ever increasing circulation of commodified goods and labor), and the extractive economies of developing nations on which the production and reproduction of such goods and labor depends" (Dalakoglou and Harvey 2012, 459). Meanwhile, the various efforts of the automobile industry have resulted in roads that in some sense simultaneously offer the dream of freedom and escape, and the experience of gridlock and frustration (Gartman 2004). Further, roads are increasingly regulated. In both Northern Ireland and in the Republic of Ireland there are laws, policies and procedures in place to ensure best practice in the use of public roads such that commuters can get to work on time, freight deadlines can be met, and they are safe environments for us to move on and through (RSA 2016). Consequently, one might expect that for road bowling to take place, a mountain of bureaucratic hurdles would need to be overcome. After all, permits are required for events such as charity runs, vintage car outings, and cycling tours that similarly utilize the public road network. Such permits are often contingent upon putting stringent safety measures in place so as to not significantly disrupt the transport concerns of a particular area. Yet, there are relatively few control measures exerted over road bowling.

Roads are often seen as transitional spaces, which enable transportation from one destination to another. They are even interpreted as non-places (Augé 1995) to which we assign meaning.

\footnotetext{
${ }^{1}$ The following clip https://www.youtube.com/watch?v=Mr7evpFmmac succinctly demonstrates the operation of the game in practice and some of its cultural nuances.
} 
Nonetheless, public roads also play host to a myriad consumption activities embedded with deep symbolic meaning (Borden 2001; Aldred and Jungnickel 2012) including road bowling. Set against this backdrop, our paper illuminates how road bowlers are able to produce symbolic space on the public roads of Ireland. We examine how consumer research has addressed space and in doing so recount how there has been a tendency to represent space as an absolute entity (Chatzidakis and McEachern 2013). In contrast, more relativistic accounts seek to understand the socio-relations that give rise to spaces, and that influence actions in space. In pursuing such a relativistic account we deploy Henri Lefebvre's (1991) triadic model of social space as a heuristic device to explore Irish road bowling, and the spaces it both produces and has produced.

\section{Space in Consumer Culture Theory}

Consumer Culture Theory (CCT) has shifted focus from the lab (Hudson and Ozanne 1988) towards the "messy contexts of everyday life" (Arnould and Thompson 2005, 875). The result is a broad canon of work, which has illuminated the potentialities for consumer researchers to study "wild and wacky worlds" (Bode and Ostergaard 2013). This has proven to be fruitful, with consumer researchers examining "how consumers consume across a gamut of social spaces" (Arnould and Thompson 2005, 875), including work on: public areas, [e.g., cities (Belk 2000), urban locales (Visconti et al. 2010; Chatzidakis et al. 2012), town squares (Warnaby 2013), parks (McEachern et al. 2012), stadiums (Bradford and Sherry 2015)], the private settings of the home and its varying expanses, [e.g., the living room (Money 2007), pantry (Coupland 2005), kitchen (Epp and Price 2008), garage (Lastovicka and Fernandez 2005; Hirschman et al. 2012)] and virtual spaces such as fan forums (Kozinets 1997), online games (O’Leary and Carroll 2013), and social media sites (Anderson et al. 2016). These studies and others have contributed valuable insights and furthered understandings of consumption, markets and culture. 
However, the key focus has been on understanding how retail spaces operate. This has led to a better understanding of, for example, the effects of store materiality on consumption practices (Rosenbaum 2005), the ways in which consumers co-opt retail spaces (Debenedetti et al. 2014; Aubert-Gamet 1997), and the various gratifications that accrue from patronage of certain stores, such as the pursuit of identity projects (Borghini et al. 2009; Roux 2014), or engagement with spectacular experiences (Peñaloza 1998). As a consequence, we now have a host of terms to characterize how retail spaces operate, e.g. servicescapes (Bitner 1992), spectacular or themed environments (Kozinets et al. 2004), consumption-scapes (Venkatraman and Nelson 2008), and heterotopias (Roux 2014).

In various ways then, consumer research has either explicitly (Visconti et al. 2010; Chatzidakis et al. 2012) or implicitly (O’Guinn and Belk 1989) addressed how a multitude of spaces, either material or ethereal (Sherry 2000), influence consumption and vice versa. Indeed, because of these studies and others, there is now increasing clarity on the motivations of consumers to consume certain spaces (e.g., Kozinets 2002), the structuring effects of space on consumption (e.g., Belk 2000; Hirschman et al. 2012), and how objects and practices relate in spaces (e.g., Epp and Price 2008). The result is a set of valuable insights into the importance of spaces as contexts for consumption (e.g., Thompson and Arsel 2004) or as objects to be consumed in order to access existential/social/cultural rewards (e.g., van Marrewijk and Broos 2012).

Given this focus, it is not surprising that space is often considered as an absolute entity (Chatzidakis and McEachern 2013); that is, space is "conceived of as an object, a container or arena in which events occur and objects exist" (Schatzki 2010, 26), something which adheres to a Newtonian logic on space (see Casey 1997). Such considerations may be the result of the emic-agentic leanings of CCT and the predisposition towards existential phenomenology as a method of inquiry (Moisander et al. 2009; Askegaard and Linnet 2011; Thompson et al. 2013) where the conceptual categories of 
researchers often become secondary to the experiential categories of consumers (Pomies and TisserDesbordes 2016). Consequently, a concept like space, that is often taken for granted, can be relegated to the periphery, regarded simply as a context for consumption or object to be consumed.

In an effort to address these issues Chatzidakis and McEachern (2013) call for more relativistic appreciations of space; that is, to move space front and center in our discourse, acknowledging how it is continuously fashioned through complex processes of production and social contestation (see Belk and Costa 1998; Peñaloza 2001; Kozinets 2002; Maclaran and Brown 2005; Visconti et al. 2010; Karababa and Ger 2011; Chatzidakis et al. 2012). Chatzidakis and McEachern (2013) indicate that other disciplines better versed in spatial theoretics (e.g., philosophy, sociology and geography) can offer theories or frameworks already suited to this goal (e.g., de Certeau 1984; Lefebvre 1991; Agnew 2005).

These disciplines tend more towards a Leibnizian ontology of space (Casey 1997) and thus consider it limiting to examine space as an object to be consumed or as a container for consumption practices (Soja 1980). Rather, it is important to understand the socio-relations that have given rise to such spaces:

"Space is not a thing among things, nor a product among other products; rather it subsumes things produced and encompasses their interrelationships in their coexistence and simultaneity - their relative order and/or disorder. It is the outcome of a set of operations and thus cannot be reduced to the rank of a simple object"

(Lefebvre 1991, 73)

We contribute to this debate and epistemology of space by exploring, through Henri Lefebvre's (1991) triadic model of social space, how socio-relations (historically and contemporaneously) bring Irish road bowling spaces into being. In so doing we begin to truly appreciate the importance of accessing the context of context (Askegaard and Linnet 2011) and contend that Lefebvre's 
framework may provide a useful heuristic device by which consumer researchers might further address the relativistic nature of space.

\section{Henri Lefebvre's Triadic Model of Social Space}

For Lefebvre "space should be seen as the site of ongoing interactions of social relations rather than the mere result of such interactions - a process of production, rather than a product" (Zhang 2006, 219). In making this claim Lefebvre was reacting to the fetishization of space that had preoccupied the social sciences (see Soja 1980; Merrifield 1993). That is, scholarly enquiry had for the most part centered on examinations of what happened in space, or how it was used, as opposed to how spaces were produced through complex social-cultural relations, i.e. relativistic appreciations of space. For him, the ways in which we operate and practice outside of institutionalized discourses of space highlighted the complex nature of how space is produced. To account for this thesis he offered a conceptualization of the co-constitutive dimensions of social space; better known as his triadic model of social space that consists of spatial practices, representations of space and spaces of representation.

\section{Spatial Practices}

For Lefebvre social space is fashioned from spatial practices (see also Soja 1980; Schatzki 1991). These are the "sequences, habits, and patterns of movement in and through physical places" (Carp 2008, 132). They ensure a sense of continuity and cohesion in social configurations (Simonsen 2005) and require forms of spatial 'competence' and 'performance' (Shields 1999) that enable us to negotiate space. For example, there are many spatial practices in operation on public roads, practices engaged in by different groups who use the same space in alternative ways, e.g. cyclists (Aldred 2010), motorcyclists (Murphy and Patterson 2010) and automobile drivers (Dant 2004). Within each of these groups there are certain understandings of how to use and organize space. 
Therefore the analysis of spatial practices concerns the production of "particular locations and spatial sets of characteristics of a given social formation” (Lefebvre 1991, 33).

\section{Representations of Space}

Space is intrinsically tied to practices and their meanings (Netto 2008; Löw 2008). For Lefebvre, representations of space refer to dominant discourses, operating in a given environment, or across society as a whole. These representations are best understood as the mental activity we use to understand and form opinions on 'physical space' (Carp 2008). These are abstract conceived notions of space that are most often controlled by those in power - technocrats, bureaucrats and planners etc., who subsume knowledge and ideology in their practice (Merrifield 1993), mediating these through their systems of capital (Simonsen 2005). They are constructed from the symbol systems and dominant social paradigms of their time (Watkins 2005), and are "tied to the social relations of production and to the order which those relations impose" (Lefebvre 1991, 33). Hence, even though representations of space are abstract, they maintain a key role in the production of space (Simonsen 2005). For example, in most countries there are set ways to behave on public roads (e.g., rules/laws of the road). These are expressed through symbols/signage (e.g., speed limits) and governed through discourses of power, such as prosecution for exceeding speed limits if caught. As a society our understanding of road practices are shaped by these dominant representations of space.

\section{Spaces of Representation}

Space, any space, is constantly subject to a multiplicity of meanings and actions. To account for this multiplicity Lefebvre offers spaces of representation, the dimension of his analytical model concerned with accounting for spatial practices that operate outside dominant representations of space. For example, people do not always adhere to the dominant ordering of space - they ignore speed limits, stop signs and other traffic management structures. This incongruence produces lived space, "the dominated space which the imagination seeks to change and appropriate ... [that] ... 
overlays physical space, making symbolic use of it" (Lefebvre 1991, 38). Fundamental to lived space or spaces of representation, then, is a deciphering of how these alternative imaginings of space are brought into being. "This discursive sphere offers complex re-coded and even de-coded versions of lived spatializations, veiled criticisms of dominant social orders and of the categories of social thought often expressed in aesthetic terms as symbolic resistance" (Shields 1992, 54). To understand these it is critical to determine the reasons or conditions that give rise to them and, as a consequence, spatial history becomes important. Nonetheless, it is difficult to pinpoint a moment in practice or a key event in the history of a space as the precipice for resistance, making this third dimension of Lefebvre's the most ambiguous (Zhang 2006). However, Lefebvre suggests that spaces of representation are "highly complex and quite peculiar, because culture intervenes here" (Lefebvre 1991, 40), often they are linked to the "clandestine or underground" side of social life (Shields 2004), and they are inherently rich in symbolic meanings (Gottdiener 1985).

In putting together this triadic model of social space Lefebvre was operating at an abstract level of theorization and, while he called for its deployment in concrete situations (Merrifield 1993), it does not lend itself easily to empirical analysis. This is due primarily to the co-constitutive nature of each of the dimensions that make up his theorization of social space. Spatial practices, representations of space and spaces of representation can and do exist all at once in one particular practice or moment (Lefebvre 1991). For example, while eating in a fine restaurant there is a certain etiquette, or representation of space, that structures the social space (e.g., the censure against resting your elbows on the table or using a mobile phone). If you did use your mobile phone at the table, this spatial practice, would create a space of representation, as it operates outside the dominant ordering of that space. Thus we can see the inter-related nature of Lefebvre's dimensions, and while the flexibility of the model allows scholars to examine the densities of practice and space (Simonsen 2005) it also proves to be its biggest hindrance in implementation (Hernes 2004). Hence, there remains a lack of clarity and consistency regarding how to approach and use the model (see Carp 2008). 
We argue that for the purposes of an analytical exercise it is appropriate to separate the constitutive elements of social space to project 'three cameras' onto a context in order to understand it (Zhang 2006). Such a separation is often undertaken in order to link both abstract theorization and empirical study (e.g., Magaudda 2011; Shove et al. 2012). Therefore, we take the following structured approach towards the study of Irish road bowling. We use spatial practices to address how road bowling spaces operate, representations of space to analyze the dominant conceptions of road usage in Ireland and how road bowling fits into these, and spaces of representation to identify how road bowling, its spaces, practices, and their meanings, have been influenced by broader socio-cultural discourses.

\section{Methodology}

This study draws on a four-year ethnographic study of Irish road bowling. Ethnography "establishes the context and subjective significance (emic) of experience for particular groups of persons but also seeks to convey the comparative and interpreted (etic) cultural significance of this experience" (Arnould and Wallendorf 1994, 485). The research involved a multi-site ethnography, where field trips to various road bowling clubs around Ireland were undertaken between September 2011 and September 2015. As a participant observer involved in one road bowling sub-group, the first researcher had extensive access to participants in that community (and in other communities) and to observers of the sport. During time spent in the field extensive notes were taken and informal interviews with other bowlers and observers were recorded. Data were also supplemented with historical and archival records, allowing for the examination of "people and events that no longer exist to be studied through interviews or observations" (Belk 1992, 341). Such records were sourced and accessed through contacts within the road bowling community and via social media accounts of road bowling clubs. These data also aided in cultural entrée to the subgroup the first author spent 
most time with, as he could demonstrate a wealth of knowledge about the game. In the final phase of the research, ten in-depth interviews were conducted (see Table 1).

(Insert Table 1)

The interviews were conducted in a narrative style (Lieblich et al. 1998). After an initial 'grand tour' question the interviews were driven principally by informants. It was felt that this style of interviewing could access varied interpretations and views on road bowling while also giving license to the informants to act as seanachaí (storytellers), given this is the stylistic manner that characterizes how road bowlers talk about the sport. Interviews took place in informants' homes and at scórs and lasted between 30 and 90 minutes. They were recorded, fully transcribed and subjected to analysis. Common themes that emerged from the data (e.g., kinship, gambling, relationships with other road users), were then member-checked by other participants of the road bowling community to ensure validity.

\section{Spatial Practices}

We start our analysis of Irish road bowling by drawing on Lefebvre's spatial practices. To do so we concentrate on analyzing the practices and cultural characteristics road bowling exhibits in order to understand how this social formation operates and hence produces space.

Every week, across Ireland thousands of road bowlers converge upon various public roads, congregating at predetermined locations. Leaving their cars, en masse they walk along a road, stopping frequently to chat to one another and wait for those playing to line their next shot. Other road users are largely ignorant of road bowling that is until they encounter such a grouping standing around on a road not letting them pass until they deem it appropriate. While at the most basic level 
of analysis this appropriation of space centers on the throwing a metal ball along a public road, road bowling practices are inherently more intricate and complex.

There was big money 5,000 a side, and we were screaming and roaring and shouting ... I don't know what people must have thought of us, must have seemed daft. I remember Deckie saying: "If you didn't know what was happening and came across this you'd say - who set all the lunatics loose". He was right, we were very bad. But that feeling is savage, you know, when it's a big scór. It's like that football hooligan film ... What's the name of it? ... Green Street.

Alan

Road bowling is made up of subgroups that form a subcultural collective. These subgroups tend to be constituted by members from certain road bowling clubs or areas. In this way, like 'football firms' in the movie Green Street to which Alan refers, these groups take on a tribal character that is tied to a sense of place (Tuan 1977). Group membership figures vary but a critical facet of gaining access to participation is engagement with and commitment to certain ritualistic consumption practices. Road bowling is thus characterized by many symbolic practices and by the enactment of some centrally important roles throughout a scór (see figures 2 and 3). ${ }^{2}$

(Insert figures 2 and 3)

These roles represent privileged positions in subgroups and are held only by those who are 'insiders' (Celsi et al. 1993). A hierarchical social structure exists and to garner insider status members must engage in normative communitas (Turner 1982), where certain roles must be played and obligations met, and 'inclusion and exclusion is determined partly by individuals' ability to meet the conditions of membership, but also their willingness to fulfill their obligations" (Lugosi

\footnotetext{
${ }^{2}$ Figures 2 and 3 depict a 'man on the sop' - a person who places a piece of grass on the road, 'the sop', as a marker to demonstrate where the road bowler should aim, and a 'road liner', a person who positions a bowler at his/her throwing point to ensure that they are correctly lined with the sop, as the geometric positioning of a bowler is crucial to the length of a bowling throw.
} 
2007, 167). In road bowling, spatial 'performance' and 'competence' (Shields 1999) are critical to a normative communitas that depends on two key consumption rituals; gambling and what we interpret as 'flaming'.

As Alan alludes to earlier, most scórs involve individuals and subgroups wagering huge sums of money on the outcome. Gambling in road bowling, unlike other forms (e.g., casino gambling or sports betting), operates on the basis of an informal rather than formal marketplace (see Sherry 1990). Road bowling, then, creates and sustains its own unregulated gambling system, a system tied up in complex rule-governed practices. These marketplaces also become important to the economy of rural Ireland as, in the absence of clubhouses, public houses are used as third spaces (Goode and Anderson 2015), meeting points before and after scórs to discuss the day’s happenings, spend winnings, and drown sorrows.

James explains how gambling in road bowling operates:

Well there is two gangs. A gang of fellas backing one fella that is bowling and there is another gang which is backing the other fella. And they will make up a stake ${ }^{3}$ on one side of the road and the other gang will make up their stake on the other side of the road. You have your own gang and no matter who you are playing they will back you. Say, if I was playing in the morning and I had a hard scór and you'd say you'd make up something small but they'd still go with you.

James here is describing the ritualistic gambling that occurs before the commencement of most scórs. He notes how a player and his/her associated supporters (sub-group) will pool their money into a collective 'stake' which is then held by a referee and is wagered against the competing bowler's subgroup's stake. Importantly this ritual is critical to road bowling as the game is not well supported by either the Irish government or other institutional bodies such as Tourism Ireland, so a levy ('tax' in bowling terms) of $10 \%$ on a winning stake is charged by Ból Chumann na hÉireann ${ }^{4}$ for its championship series, and similarly by local clubs for in-house tournaments they run. Despite

\footnotetext{
3 "Stake" is a road bowling term to denote the collective funds pooled from members of a road bowling subgroup when gambling on the outcome of a scór.

${ }^{4}$ Ból Chumann na hÉireann is a voluntary-run association that organizes road bowling throughout Ireland.
} 
gambling being recognized as a potentially addictive and problematic practice (Cotte and Latour 2010), the 'tax' collected from stakes is critical to supporting Ból Chumann na hÉireann and local bowling clubs. This creates an interesting situation whereby the informal market of gambling in this instance is actively encouraged and sustains the sport.

Normally an insider from each subgroup is given the task (or role) of tallying a stake - the stakeholder. The first author fulfilled this role during his time in the field (see figure 4).

(Insert figure 4)

During initial data collection, the normative procedures surrounding the collection of stakes remained vague:

Denis was bowling a championship scór this evening. Before it I heard that he was fancied to win so I went with the mindset that I was going to put fifty euros on him. Alan told me that this was the minimum I should try to bet. I didn't realize what he meant by "try". Jump ahead to me arriving at the location of the scór and seeking to place my bet. I stepped out of my car and immediately saw Teddy surrounded by a crowd of people. I wasn't really sure what was happening but I soon recognized that in order to place a bet on Denis, it was imperative that I give my money to Teddy. I sought to barge my way through the large crowd towards him. As I neared the front of the gathering, I was holding out my yellow note towards Teddy, mimicking the procedural sequence of others there; which comprised of a sort of polite battle for supremacy of space surrounding him. Yet there was no eye contact from Teddy towards me. I remember thinking: "Why isn't Teddy taking my fifty, what's wrong?" Eventually he looked up at me, begrudgingly grasped my fifty euro note from my hand and looked away. I turned back to leave the prevailing crowd and was left wondering: "What was all that about?"

Ethnographic Fieldnotes

Teddy's aversion to take the bet demonstrates how not everyone can contribute to the stake of a road bowler. Only those who are a part of the 'gang' may enter, particularly if that bowler is favored to win the scór. While able to place a bet on this occasion (Teddy most likely feeling some sympathy for a naïve academic), a stakeholder will normally only collect monies from other 
insiders who have earned the right, or entitlement, to participate in the stake. Importantly, however, the right to enter a stake is also an obligation.

No matter how hard your scór is and even if you really have no chance they will still go with you anyway. They are fiercely loyal no matter how hard you have it they'll still throw in some 10 or 20 euros and they will always make up a few bob.

James

A 'hard scór' refers to a situation where a bowler is not favored to win. Yet the etiquette demands that a small bet is wagered. This responsibility goes unspoken but this form of tacit knowledge is fundamental to gaining access to the 'gang'. The obligation to gamble also creates a sense of weness where subgroups simultaneously experience financial gains and losses. At times this obligation can be onerous for members of subgroups, as they must gamble on each scór in which a member of their group is participating.

Another of road bowling's core rituals fosters similar feelings of excitement and actually heightens the gambling experience. ${ }^{5}$ Alan explains:

If I was bowling you now, my gang of people would be shouting for me and, in fairness, at times there is harsh stuff said. But it'd be only trying to put your opponent off and it is just kind of trying to intimidate your opponent ... that is what it is basically. You do get a good buzz out of it too ... you can get lost in the moment. You have your money on and your looking like you are going to win and it is the craic and the buzz about winning .... it drives you on then.

What Alan is explaining here, is what we interpret as 'flaming'. The term is offered by Kozinets (1998) to denote how Internet trolls attack or send derogatory messages to others on Internet forums. The term is also useful to describe the ritualistic shouting that occurs at scórs. The shouting, the use of cultural jargon, and the celebratory jumping up and down when a player from your subgroup throws a good shot, represent a ritual of intimidation, support and/or devotion to

\footnotetext{
5 Turner (1982) identifies gambling as a practice that gives people states of flow. However, states of flow from gambling in road bowling are dependent on normative communitas, as to place a bet in a stake you must adhere to certain norms. Additionally these states are exacerbated by the performance of flaming where the we-ness of collective celebration intensifies the experience of gambling.
} 
one's own subgroup. Through these "symbolic modes of expression" (Schouten and McAlexander 1995, 43) road bowlers develop existential communitas where they can "become totally absorbed into a single synchronized fluid event" (Turner 1982, 48). They "get lost in the moment" as Alan puts it, and hence members of subgroups are able to experience states of flow and affectual bonding (Csikszentmihalyi 1990). These states are critical to road bowling as they support kinship within subgroups and rivalries with other subgroups.

Gambling and flaming are key spatial practices that help road bowlers produce and reproduce road bowling spaces on Irish public roads. There are forms of spatial performance and competency tied to both that are dependent on normative and existential communitas. Having examined the sequences, habits or patterns of this social configuration and how its members negotiate the spaces it produces, it is now important to determine road bowling's relationship with the dominant discourses of space that surround Irish public roads.

\section{Representations of Space}

In the main, road space is infrastructural and culturally oriented towards vehicles (Aldred and Jungnickel 2012). Commercial and market concerns undoubtedly contribute to, and drive such orientations. For example, roads and effective transportation networks are critical to foreign direct investment, international commerce and hence a country's GDP through its balance of payments and balance of trade. Roads, then, are central entities in market systems where exchange is very often predicated on their efficiency. For a country like Ireland which is laboring its way out of economic recession these factors are of utmost importance. Moreover, "technocrats bureaucrats and planners" (Lefebvre 1991) dictate and administer a host of policies, procedures and laws to ensure that vehicles on Irish roads are ordered, controlled and most importantly catered to (RSA 2016). 
The use of public roads is not always clear cut, however. Many practices evidence overt and tacit struggles over how public space should be consumed (Borden 2001; James 2000). Public space is continually negotiated, acted upon, produced and reproduced in dialectical and dialogical ways.

Basically you'd be driving down the road and you'd see a group of them and there'd be one guy sort of at the front who would just like motion with his hand for you to slow down and you'd just have to wait until they're finished and they'll motion you to go on then. But it is like ... it's not very official.

Oisín

Oisín describes how road bowlers appropriate public space (Visconti et al. 2010) such that roads are not roads in their conventional representational sense. In essence they are, at least momentarily, spaces of play rather than spaces of transport. His indication that "it's not very official" highlights how road bowling inverts what he, and others consider to be normative road practices, leading some to proclaim the activity as "mad".

It is a bit mad isn't it ... with the cars, bikes and cyclists passing. But once you get your head around it, it seems to be an interesting game ... I mean it is a strange occurrence you don't see things like this in many places

Scott

Such madness is illustrated in the clip offered in the introduction, where regular road users and road bowlers pass by in very close proximity to one another. As a consequence, this "strange occurrence" creates a potentially hazardous space, where not only are the economic efficiencies of market transportation hindered, but there is a very real danger posed to road bowlers by passing traffic and to passing traffic by flying bowls. It would be reasonable to expect the various regulatory authorities with responsibility for public roads to exert measures of control over such activities. Yet these institutions generally accept scórs as something towards which "a blind eye" can be turned. Indeed because of this, tensions arise over the playing of the game. As Peggy and Denis opine:

Jesus, would they ever keep in off the road. They wouldn't get out of the way if you asked them. I hate them. People can't get anywhere when they are around.

Peggy

A lot of people don't like the bowling on the roads at all. People that have nothing to do with it. And I suppose a lot of [bowlers] don't do themselves favors either by standing 
out in the middle of the road when the cars are trying to go through ... like, they kind of don't move out of the way a lot of them.

Denis

Peggy's comment is indicative of many people who come across road bowling. Road users pay taxes that are designed to ensure the maintenance and efficiency of road networks. They expect not to be impeded by those whose purpose they deem to be outside regular usage. Posts on social media and complaints to local councils bemoaning the practice are commonplace (Lane 2005), where vehicle users and locals lament the lack of concern road bowlers exhibit towards traffic. Such antagonism emerges from what Denis suggests is a sense of entitlement that bowlers possess in respect of public roads. After all, road bowlers also pay taxes and maintain that they have as much right to the roads as others. "Standing out in the middle of the road", therefore, becomes a cultural expression that signals a claim to road - a form of symbolic power (Bordieu 1984) that determines that right of passage is not necessarily connected to the economic necessity of transport. One interviewee Sharon, a bowler who also works as a driving instructor, expands on these issues:

I don't see why it should be stopped or anything ... by no means. It's a sport ... like it's [been] there for years and years and years ... It's simply a culture thing.

Sharon

As someone who teaches others the precepts of correct road usage, any conflict Sharon experiences about the appropriation of public roads is resolved through the belief that road bowling has earned its place on Irish roads. In this case 'culture' trumps dominant representations. In an effort to make more sense of these issues we now turn to Lefebvre's spaces of representation to appreciate road bowling in relation to the broader spatial and physical history of Ireland.

\section{Spaces of Representation}

Ireland has a checkered past regarding the sovereignty of its land. Invasions from the Vikings, the Normans, and most notably the British have left many Irish people's national and cultural identities embedded in discourses of resistance (Cairns and Richards 1988; McGuire and Hassan 2012). This 
history has also left its mark on road bowling. Although brought to Ireland by either Cromwellian Dutch soldiers or settlers from the British textile trade in the seventeenth century, by the midnineteenth and early twentieth century, the game had been wholeheartedly adopted by Irish residents (Murray 1976). This period in Irish history was characterized by revolutionary attempts to undermine British rule. None of these attempts were successful until 1921. Until this time, Irish cultural sports (e.g., Gaelic football and hurling), were subject to stringent and oppressive controls by the British Crown (Cronin 1999). The same is true of road bowling and hard labor or prison terms were often enforced upon those caught playing the game (see figures 5 and 6).

(Insert figures 5 and 6)

Lane $(2005,33)$ notes how these attempts "to suppress the sport gave road bowling, in the eyes of some nationalists, additional credibility as a national pastime under threat from a hostile British state". In this way road bowling became associated with Irish nationalism and thus was seen as a symbolic act (Gottdiener 1985) of rebellion or opposition to British occupation. ${ }^{6}$ It even became endorsed as a 'Celtic' game to be preserved and enjoyed (de Búrca 1989), by the Gaelic Athletic Association (GAA). ${ }^{7}$ After the War of Independence, however, road bowling was no longer suppressed. Ireland shifted from an agrarian society ${ }^{8}$ to an industrialized, neo-liberal state with an attendant focus on the value of roads to economic infrastructure (Keohane and Kuhling 2004). The position of the GAA in relation to road bowling also shifted such that the game was considered "too dangerously and anti-social a pastime in a world becoming increasing conscious of the value of roads" (Mandle 1987, 17). The sport therefore developed on the periphery of society, being sustained in areas where staunch nationalist ideology remained.

\footnotetext{
${ }^{6}$ See the attached clip which references road bowling's history of resistance https://youtu.be/06Dx4KZgktA

${ }^{7}$ The Gaelic Athletic Association is an Irish and international amateur sporting and cultural organization focused primarily on promoting Gaelic games.

${ }^{8}$ The term for road in Gaelic is "bóthar", which literally means a passage for cattle.
} 
West Cork is the home of bowling in Cork and bowling is a big part of West Cork and it's the same in South Armagh if you are a member of a family that has bowled with years you're going to bowl ... like it's as simple as that.

Alan

Alan indicates how road bowling has specific place attachment bonds (Debenedetti et al. 2014) to West Cork and South Armagh. These two areas of Ireland have traditionally held strong ties to Irish republicanism, and sport has long operated as a central vehicle for the transmission of this ideology and identity (Duffy 2014). Unsurprisingly then, given the game's history, the sport has survived most strongly in these areas. The legacy of resistance has been integral to the sport's longevity and is one of the core reasons why road bowling has been able to negate contemporary, institutionalized modes of "discipline and punishment" (Foucault 1977).

Contemporary road bowlers, just like their predecessors, demonstrate an apathy or resistance towards the structural obligations (Turner 1982) of institutional powers. Challenging the dominant discourses of the technocrats, road bowlers themselves become autocrats seeking to control the everyday use of public roads that is dominated by vehicles. The continued practice of the sport can thus be seen to represent a form of collision culture, that is, where the "symbolic orders and imaginative structures of traditional community and modern society co-exist, intermingle and collide with one another" (Keohane and Kuhling 2004, 3). This culture has become a part of the habitus (Bordieu 1984) of road bowling locales - "it's simply a culture thing" [Sharon] - and thus sustains the practice in a country increasingly concerned with road safety practices. In this way, space as a broader socio-cultural structuring force has been critical to road bowling.

\section{Discussion}

Roads can often be thought of as non-places (Augé 1995); those spaces that are too insignificant to be labeled as meaningful. Alternatively, we see them as liminal spaces, betwixt and between (Turner 1969), departure and destination points. In this paper we highlight how road bowlers 
appropriate the institutionalized public space of the road. In pursuing their sport road bowlers are simultaneously vilified and neglected, ignored by regulatory institutions (policing bodies, road safety authorities) and key cultural bodies (e.g. Tourism Ireland, the GAA). Road bowling itself, then, exists betwixt and between "positions assigned and arrayed by law, custom and convention" (Turner 1969, 95). In this sense, public roads and the norms that surround their consumption have projected a liminal quality onto road bowling. Support for this is exemplified by the consumption of the game. Once affiliated you must abide by its rules, customs, rituals - you must attend scórs, you must gamble even if likely to lose. Road bowling requires work, there are obligatory rites of passage (Van Gennep 1960), and the game can be filled with dread and fear (Turner 1982) over financial losses which may be suffered.

Road bowlers turn the liminal space of roads into transitory dwelling places (see Shortt 2015). They convert undifferentiated space (Tuan 1977) into meaningful places (Casey 1993), places that sustain cultural place narratives of history, heritage and Celtic identity. In this way roads are not always just roads; where road bowling is prevalent, they are bowling roads enveloped in relationships, history and identity. The conversion of roads in this way is effected by imbuing a hermetic space, a public road where access is open to all, with hestial characteristics (see Casey 1993), where the road to a degree, becomes closed and private. Many can attend a scór while it is occurring, but for a short period at least the space is ultimately controlled by road bowlers. Others who use the space must wait for road bowlers to let them pass. Outsiders who wish to access the game's existential communitas, its revelry, cannot do so unless they adhere to its forms of normative communitas (e.g. gambling obligations). This finding enables us to not only explicate the important differences between normative and existential communitas within consumer research, but also to fundamentally reinterpret Turner's delineation of the relationship between these two aspects. 
According to Turner $(1982,47)$ existential communitas is a complete and undiluted separation from social structure that "can seldom be sustained for long. Communitas itself soon develops a (protective social) structure, in which free relationships between individuals become converted into norm-governed relationships between social personae". This suggests that existential communitas becomes restructured as normative communitas - "the attempt to capture and preserve spontaneous communitas in a system of ethical precepts and legal rules" (Turner and Turner 1978, 232). Experiential accounts of consumption in CCT figure communitas as being imbued by certain extraordinary experiences involving flow and/or catharsis (Arnould and Price 1993; Celsi et al. 1993; Tumbat and Belk 2011). Like Turner, CCT researchers position existential communitas as a precursor to communitas in its community or normative sense. However, our findings point towards an inversion between existential and normative communitas whereby normative communitas must be engaged with in order to access existential communitas. Normative communitas can thus determine our ability to engage with certain spaces.

For example, access to the spaces of consumption in road bowling is predicated on the ability to fulfill roles and obligations in subgroups. Only when normative communitas is navigated can participants experience states of flow the sport can offer (e.g., through gambling or flaming rituals). This requires work where spatial knowledge must be garnered. Adherence to rules, etiquette, the learning of language, and consuming in the 'right' way is crucial. Goulding et al. (2002) capture the same sense by noting how in order for clubbers to experience existential communitas, losing it with others on the dance floor, they must first carefully chose costumes, engage in complex queuing norms and be granted acceptance to the space by the "fashion police". Similarly, at Mountain Men rendezvous access to 'shinin' times (Belk and Costa 1998) is also determined by the wearing of appropriate attire, along with the consumption of certain objects and practices. At Burning Man (Kozinets 2002), a festival entirely constructed around the allure of existential communitas, certain norms and ways of behaving must be adhered to (e.g. non-vending). Even during white water 
rafting trips "guides impose rules and order on the trip from the beginning that prefigure the development of community" (Arnould and Price 1993, 34). Supplies must be loaded and unloaded, cooking and cleaning duties are required. Our concern with experiential views of consumption in CCT, rather than more spatial perspectives (see Debenedetti et al. 2014), has allowed us to bypass the important role that normative communitas plays in facilitating access to existential communitas. While Turner (1982) attempted to eschew the idea that communitas had a territorial locus, we highlight here how communitas is indeed heavily governed and dependent upon knowledge of spatial characteristics. These may not be prefixed to certain locations but in this way, space plays a hugely important structuring role.

Our chosen heuristic has been fundamental to explicating these findings. In foregrounding spatial thought, Lefebvre has facilitated an understanding of the centrality of spatial competency and knowledge as fundamental to accessing states of flow, those that make subcultural (Schouten and McAlexander 1995) or festive experiences (Bradford and Sherry 2015) so appealing to consumers. Yet, despite its apparent potential, the few consumer researchers who have engaged with Lefebvre's model have not exhausted its possibilities. Aubert-Gamet (1997) argues the potentiality of the model, and Houliez (2010) successfully operationalizes the dimension of spatial practices. de Burgh-Woodman (2012) attempts to operationalize the tripartite nature of the model, but due to methodological difficulties, does not fully realize the analytical depth that it offers.

What we provide here is a systematic understanding of how Lefebvre's framework can be employed as a heuristic device. In particular, our approach highlights how it can enable a tripartite series of evaluations, at micro, meso and macro levels of analysis. For example, our examination of the spatial practices of road bowling has demonstrated the importance of certain rituals to the game's production of social spaces. This affords us a micro-sociological account of sub-group dynamics and the lived experiences of road bowlers in practicing the sport. Using Lefebvre's representations 
of space, we were then able take up a meso-level analysis, arguing how the production of space fits within broader discourses of Irish road spaces and other road users in certain locales. Finally, we used spaces of representation as a basis to examine road bowling at a macro level, identifying how broader socio-historic patternings of consumption have influenced and sustained the sport. This has allowed us the ability to re-interpret meaning by overlaying socio-cultural insight and thus demonstrate the importance of the context of context (Askegaard and Linnet 2011) to road bowling, and its continued longevity. By utilizing Lefebvre's framework we have been able to position space as a "macro-systemic and social theoretical concept for understanding the life worlds of consumers that go beyond what can immediately be detected in consumer accounts of lived experiences" (Askegaard and Linnet 2011, 399). Our deployment of Lefebvre, therefore, has potential application for consumer researchers who wish to embrace more spatial perspectives, further relativistic appreciations of space, and highlight the importance of the context of context in empirical enquiry.

\section{Conclusion}

In this paper, we contribute to the ways in which space and geographical histories are seen as important socio-historic structuring forces of consumption (see also Chatzidakis et al. 2012). This is important as the relationship between context, particularly when understood as spatial context, and meaning is iterative and complex. We call for CCT to embrace more spatial perspectives in order to shed new light on how they can further inform our understandings of space, place, consumption, markets and culture and the complex nature of their inter-relationships. While we have promoted Lefebvre here, it would be remiss not to call for further examination of other spatial analytical frameworks (e.g., Hagerstand 1978; Agnew 2005) that are offered across the social sciences. We believe these require interrogation by consumer researchers in order to further emphasise the centrality of space to consumption and move discourse on the topic forward in CCT. As we have demonstrated here, through Lefebvre, they may also have utility in providing new ways to access 
insights into the complexities of contexts of consumption and their relationships with markets and culture.

\section{References}

Agnew, John A. 2005. "Space: place.” In Spaces of Geographical Thought: Deconstructing Human Geography's Binaries. edited by Paul Cloke., Ron Johnston, and Ronald John Johnston. London: Sage, pp. 81-96.

Aldred, Rachel. (2010) "On the outside': constructing cycling citizenship." Social \& Cultural Geography 11 (1): 35-52.

Aldred, Rachel, and Jungnickel, Katrina. 2012. "Constructing Mobile Places between 'Leisure' and 'Transport': A Case Study of Two Cycle Rides.” Sociology 46 (3): 523-539.

Anderson, Stephanie, Kathy Hamilton, and Andrea Tonner. 2016. "Social labour Exploring work in consumption." Marketing Theory doi: 1470593116640598.

Arnould, Eric J., and Linda L. Price. 1993. "River magic: Extraordinary experience and the extended service encounter." Journal of Consumer Research 20 (1): 24-45.

Arnould, Eric J. and Craig, J. Thompson. 2005. "Consumer culture theory (CCT): Twenty years of research." Journal of Consumer Research 31 (4): 868-882.

Arnould, Eric J. and Melanie Wallendorf. 1994. "Market-oriented Ethnography: Interpretation Building and Marketing Strategy Formulation.” Journal of Marketing Research 31 (4): 484-504.

Askegaard, Søren, and Jeppe T. Linnet. 2011. "Towards an Epistemology of Consumer Culture Theory: Phenomenology and the Context of Context." Marketing Theory 11 (4): 381-404.

Aubert-Gamet, Vernonique. 1997. "Twisting servicescapes: diversion of the physical environment in a re-appropriation process." International Journal of Service Industry Management 8 (1): 26-41.

Augé, Marc. 1995. Non-places; Introduction to an Anthropology of Supermodernity. Translated by John Howe. London: Verso.

Belk, Russell W. 2000. "May the farce be with you: On Las Vegas and consumer infantalization" Consumption, Markets and Culture 4 (2): 101-124.

Belk, Russell W. 1992. "Moving possessions: an analysis based on personal documents from the 1847-1869 Mormon migration.” Journal of Consumer Research 19 (3): 339-361.

Belk, Russell W., and Janeen A. Costa. 1998. "The Mountain Man Myth: A Contemporary Consuming Fantasy." Journal of Consumer Research 25 (3): 218-240.

Bitner, Mary J. 1992. "Servicescapes: the impact of physical surroundings on customers and employees." The Journal of Marketing 56 (2): 57-71.

Bode, Matthias, and Per Østergaard. 2013. "The wild and wacky worlds of consumer oddballs' Analyzing the manifestary context of consumer culture theory." Marketing Theory 13 (2): 175-192. 
Borden, Iain. 2001. Skateboarding, Space and the City: Architecture and the Body. Oxford: Berg.

Bourdieu, Pierre. 1984. Distinction: A social critique of the judgement of taste. Cambridge: Harvard University Press.

Borghini, Stefania, Nina Diamond, Robert V. Kozinets, Mary Ann McGrath, Albert M. Muniz, and John F. Sherry. 2009. "Why are Themed Brandstores so Powerful? Retail Brand Ideology at American Girl Place.” Journal of Retailing 85 (3): 363-375.

Bradford, Tonya Williams, and John F. Sherry. 2015. "Domesticating Public Space through Ritual: Tailgating as Vestaval.” Journal of Consumer Research 42 (1): 130-151.

Cairns, David and Shaun Richards 1988. Writing Ireland: Colonialism, Nationalism and Culture. Manchester: Manchester University Press.

Carp, Jana. 2008. "Ground-Truthing Representations of Social Space Using Lefebvre's Conceptual Triad.” Journal of Planning Education and Research 28 (2): 129-142.

Casey, Edward 1993. Getting back into place: Toward a renewed understanding of the place-world. US: Indiana University Press.

Casey, Edward. 1997. The Fate of Place: A Philosophical History. Berkeley and Los Angeles: University of California Press.

Celsi, Richard L., Randall L. Rose, and Thomas W. Leigh. 1993. "An exploration of high-risk leisure consumption through skydiving." Journal of Consumer Research 20 (1): 1-23.

Chatzidakis, Andreas, and McEachern, Morven 2013. "Consumption in and of Space and Place", Advances in Consumer Research 10: 335-335.

Chatzidakis, Andreas, Pauline Maclaran, and Alan Bradshaw. 2012. "Heterotopian Space and the Utopics of Ethical and Green Consumption.” Journal of Marketing Management 28 (3-4): 494-515.

Cotte, June, and Kathyrn Latour 2009. "Blackjack in the kitchen: Understanding online versus casino gambling." Journal of Consumer Research 35 (5): 742-758.

Coupland, Jennifer. 2005. "Invisible brands: An ethnography of households and the brands in their kitchen pantries." Journal of consumer research 32 (1): 106-118.

Cronin, Mike. 1999. Sport and nationalism in Ireland: Gaelic games, soccer and Irish identity since 1884. Dublin: Four Courts Press Ltd.

Csikszentmihalyi, Mihaly. 1990. Flow: The psychology of optimal performance. New York: Cambridge University Press.

Dalakoglou, Dimitris, and Penny Harvey. 2012. "Roads and anthropology: ethnographic perspectives on space, time and (im) mobility." Mobilities 7 (4): 459-465.

Dant, Tim. 2004. "The driver-car." Theory, Culture \& Society 21 (4-5): 61-79.

Debenedetti, Alain, Harmen Oppewal, and Zeynep Arsel. 2014. "Place Attachment in Commercial Settings: A Gift Economy Perspective." Journal of Consumer Research 40 (5): 904-923.

De Búrca, Marcus. 1989. Michael Cusack and the GAA. Dublin: Gill and Macmillan. 
de Burgh-Woodman, Helene. 2012. "Cars for Sale! An Ethnography of the Collusion of Space and Consumption in Power and Agency Struggles." Advances in Consumer Research 40: 496-501.

de Certeau, Michel. 1984. The Practice of Everyday Life. Berkeley: University of California Press.

Duffy, Dee. 2014. "Situating Men within Local Terrain: A Sociological Perspective on Consumption Practices." In Consumer Culture Theory, edited by John W. Schouten, Diane M. Martin, Russell Belk, 81-97. UK: Emerald Group Publishing Limited.

Epp, Amber M. and Linda L. Price. 2008. "Family Identity: A Framework of Identity Interplay in Consumption Practices." Journal of Consumer Research 35 (1): 50-70.

Flower, John. 2004. "A road is made: roads, temples, and historical memory in Ya'an county, Sichuan." Journal of Asian Studies 63 (3): 649-685.

Foucault, Michel. 1977. Discipline and the Punish: The Birth of the Prison, translated by Alan Sheridan. New York: Random House.

Gartman, David. 2004. "Three ages of the automobile: the cultural logics of the car." Theory, Culture \& Society 21 (4-5): 169-195.

Goode, Amy, and Stephanie Anderson. 2015. "“It's Like Somebody Else's Pub”: Understanding Conflict in Third Place." NA-Advances in Consumer Research Volume 43.

Goodwin, Katherine. 2010. "Reconstructing automobility: the making and breaking of modern transportation." Global Environmental Politics 10 (4): 60-78.

Gottdiener, Mark. 1985. Social production of urban space. Austin: University of Texas.

Goulding, Christina, Avi Shankar, and Richard Elliott. 2002. "Working weeks, rave weekends: identity fragmentation and the emergence of new communities." Consumption, Markets and Culture 5 (4): 261-284.

Hägerstrand, Torsten. 1978. "Survival and Arena: On the Life History of Individuals in Relation to Their Geographical Environment." In Timing Space and Spacing Time: Human Activity and Timegeography, edited by Tommy Carlstein, Don Parkes, and Nigel Thrift, 122-45. London: Edward Arnold.

Hernes, Tor. 2004. The spatial construction of organization. Amsterdam; John Benjamins Publishing.

Hirschman, Elizabeth C., Ayalla Ruvio, and Russell W. Belk. 2012. "Exploring Space and Place in Marketing Research: Excavating the Garage.” Marketing Theory 12 (4): 369-389.

Houliez, Chris. 2010. "Branding places or branding spatial practices \& quest; Retail spaces in the age of mixed realities." Place Branding and Public Diplomacy 6 (2): 87-96.

Hudson, Laurel A. and Julie L. Ozanne. 1988. "Alternative ways of seeking knowledge in consumer research." Journal of consumer research 14 (4): 508-521.

James, Leon. 2000. Road rage and aggressive driving: Steering clear of highway warfare. New York: Prometheus Books. 
Karababa, Eminegül, and Güliz Ger. 2011. "Early modern Ottoman coffeehouse culture and the formation of the consumer subject." Journal of Consumer Research 37 (5): 737-760.

Keohane, Kieran, and Carmen Kuhling. 2004. Collision culture: transformations in everyday life in Ireland. Dublin: Liffey Press.

Kozinets, Robert V. 2002. "Can Consumers Escape the Market? Emancipatory Illuminations from Burning Man.” Journal of Consumer Research 29 (1): 20-38.

Kozinets, Robert V. 1997. "I Want to Believe": A Nethnography of the'X-Philes' Subculture of Consumption. Advances in consumer research 24: 470-475.

Kozinets, Robert V. 1998. “On netnography: Initial reflections on consumer research investigations of cyberculture." Advances in consumer research 25: 366-371.

Kozinets, Robert V., John F. Sherry, Diana Storm, Adam Duhachek, Krittinee Nuttavuthisit, and Benet DeBerry-Spence. 2004. "Ludic Agency and Retail Spectacle." Journal of Consumer Research 13 (3): 658-672.

Lane, Fintan. 2005. Long Bullets: A History of Road Bowling in Ireland. Ardfield, Cork: Galley Head Press.

Lastovicka, John, and Karen Fernandez. 2005. "Three paths to disposition: The movement of meaningful possessions to strangers." Journal of Consumer Research 31 (4): 813-823.

Lefebvre, Henri. 1991. The Production of Space. Oxford: Blackwell.

Lieblich, Amia, Rivka Tuval-Mashiach, and Tamar Zilber. 1998. Narrative Research: Reading Analysis and Interpretation. Thousand Oaks, CA: Sage.

Löw, Martina. 2008. "The Constitution of Space The Structuration of Spaces Through the Simultaneity of Effect and Perception.” European Journal of Social Theory 11 (1): 25-49.

Lugosi, Peter. 2007. "Queer consumption and commercial hospitality: Communitas, myths and the production of liminoid space." International journal of sociology and social policy 27 (3/4): 163174.

Maclaran, Pauline, and Stephen Brown. 2005. "The center cannot hold: consuming the utopian marketplace" Journal of Consumer Research 32 (2): 311-323.

Magaudda, Paolo. 2011. "When materiality 'bites back': Digital music consumption practices in the age of dematerialization." Journal of Consumer Culture 11 (1): 15-36.

Mandle, William F. 1987. The Gaelic Atheltic Association and Irish Nationalist Politics 18841924. Dublin: Gill and Macmillan.

McEachern, Morven, Gary Warnaby and Fiona Cheetham. 2012. "Producing \& Consuming Public Space: A 'Rhythmanalysis' of the Urban Park." In: Association for Consumer Research: Appreciating Diversity, 4th - 7th October 2012, Vancouver, Canada.

McGuire, Andrew, and David Hassan. 2012. "Cultural nationalism, Gaelic Sunday and the Gaelic Athletic Association in early twentieth century Ireland." The International Journal of the History of Sport 29 (6): 912-923. 
Merrifield, Andrew. 1993. "Place and space: a Lefebvrian reconciliation." Transactions of the institute of British geographers 18 (4): 516-531.

Moisander, Johanna, Anu Valtonen, and Heidi Hirsto. 2009. "Personal interviews in cultural consumer research-post-structuralist challenges." Consumption, Markets and Culture 12 (4): 329348.

Money, Annemarie. 2007. "Material Culture and the Living Room The appropriation and use of goods in everyday life." Journal of Consumer Culture 7 (3): 355-377.

Murphy, Stephen, and Maurice Patterson. 2011. "Motorcycling edgework: A practice theory perspective." Journal of Marketing Management 27 (13-14): 1322-1340.

Murray. FR Raymond. 1976. The Armagh Bullet Thrower. Armagh: History.

Netto, Vinicius. 2008. "Practice, space, and the duality of meaning." Environment and Planning D: Society and Space 26 (2): 359-379.

Newman, Daniel. 2016. "The car and the commons." Review of Radical Political Economics 48 (1): 53-65.

O'Guinn, Thomas C. and Rusell W. Belk. 1989. "Heaven on earth: consumption at Heritage Village, USA.” Journal of Consumer Research 18 (2): 227-238.

O'Leary, Killian, and Conor Carroll. 2013. "The online poker sub-culture: Dialogues, interactions and networks." Journal of Gambling Studies 29 (4): 613-630.

Peñaloza, Lisa. 2001. "Consuming the American West: Animating cultural meaning and memory at a stock show and rodeo." Journal of consumer research 28 (3): 369-398.

Peñaloza, Lisa. 1998. "Just Doing It: A Visual Ethnographic Study of Spectacular Consumption Behavior at Nike Town." Consumption, Markets and Culture 2 (4): 337-400.

Pomiès, Anissa. and Elisabeth Tissier-Desbordes. 2016. "Constructing the object of research in the manner of Piet Mondrian An integrative epistemology for consumer research." Marketing Theory, doi: 1470593116635875.

Road Safety Authority. 2016. "Road Safety." accessed October 112016. http://www.rsa.ie/en/RSA/Road-Safety

Rosenbaum, Mark S. 2005. "The symbolic servicescape: your kind is welcomed here." Journal of Consumer Behaviour 4 (4): 257-267.

Roux, Dominique. 2014. "Revisiting (not so) commonplace ideas about the body: Topia, utopia and heterotopia in the world of tattooing." In Consumer Culture Theory (pp. 59-80). United Kingdom: Emerald Group Publishing Limited.

Schatzki, Theodore R. 1991. "Spatial Ontology and Explanation." Annals of the Association of American Geographers 81 (4): 650-670.

Schatzki, Theodore R. 2010. The Timespace of Human Activity: On Performance, Society, and History as Indeterminate Teleological Events. UK: Lexington Books. 
Schouten, John W. and James H. McAlexander. 1995. "Subcultures of consumption: An ethnography of the new bikers." Journal of Consumer Research 22 (1): 43-61.

Sheller, Mimi, and John Urry. 2003. "Mobile transformations of 'public' and 'private' life." Theory, Culture \& Society 20 (3): 107-125.

Sherry, John F. 1990. "A sociocultural analysis of a Midwestern American flea market." Journal of Consumer Research 17 (1): 13-30.

Sherry Jr, John F. 2000. "Place, Technology, and Representation." Journal of Consumer Research 27 (2): 273-278.

Shields, Rob. 2004. "Henri Lefebvre". In Kitchin, Rob, Gill Valentine, and Phil Hubbard, (eds.) Key thinkers on space and place. pp. 208-213. London: Sage.

Shields, Rob. 1999. Lefebvre, love, and struggle: Spatial dialectics. London: Routledge.

Shields, Rob. 1992. Places on the Margin: Alternative Geographies of Modernity. London: Routledge.

Shortt, Harriet. 2015. "Liminality, space and the importance of 'transitory dwelling places' at work." Human relations 68 (4): 633-658.

Shove, Elizabeth, Mika Pantzar, and Matt Watson. 2012. The dynamics of social practice: Everyday life and how it changes. London: Sage Publications.

Simonsen, Kristen. 2005. "Bodies, sensations, space and time: the contribution from Henri Lefebvre." Geografiska Annaler. Series B. Human Geography 87 (1): 1-14.

Soja, Edward W. 1980. "The Socio-spatial Dialectic." Annals of the Association of American Geographers 70 (2): 207-225.

Thompson, Craig J., Eric Arnould, and Markus Giesler. 2013. "Discursivity, difference, and disruption: Genealogical reflections on the consumer culture theory heteroglossia." Marketing Theory 13 (2): 149-74.

Thompson, Craig J., and Zeynep Arsel. 2004. "The Starbucks Brandscape and Consumers' (Anticorporate) Experiences of Glocalization.” Journal of Consumer Research 31 (3): 631-642.

Toal, Brian. 1996. Road Bowling in Ireland. Monaghan: R\&S Printers.

Tuan, Yi-Fu. 1977. Space and place: The perspective of experience. Minnesota: University of Minnesota Press.

Tumbat, Gülnur, and Russell W. Belk. 2011. "Marketplace tensions in extraordinary experiences." Journal of Consumer Research 38 (1): 42-61.

Turner, Victor. 1982. From Ritual to Theatre: The Human Seriousness of Play. New York: PAJ Pubs.

Turner, Victor, and Edith, L. B. Turner. 1978. Image and pilgrimage in Christian culture: Anthropological perspectives. New York: Columbia University Press. 
Turner, Victor. 1969. The Ritual Process: Structure and Anti-Structure. Chicago: Aldine.

Van Gennep, Arnold. 1960. The rites of passage. Chicago: Chicago University Press.

van Marrewijk, Alfons, and Maaike Broos. 2012. "Retail Stores as Brands: Performances, Theatre and Space." Consumption Markets and Culture 15 (4): 374-391.

Venkatraman, Meera, and Teresa Nelson. 2008. "From servicescape to consumptionscape: a photoelicitation study of Starbucks in the New China" Journal of International Business Studies 39 (6): 1010-1026.

Visconti, Luca M., John F. Sherry Jr, Stefania Borghini, and Laurel Anderson. 2010. "Street Art, Sweet Art? Reclaiming the 'Public' in Public Place." Journal of Consumer Research 37 (3): 511 529.

Warnaby, Gary. 2013. "Synchronising retail and space: using urban squares for competitive place differentiation." Consumption Markets \& Culture 16 (1): 25-44.

Watkins, Ceri. 2005. "Representations of space, spatial practices and spaces of representation: An application of Lefebvre's spatial triad.” Culture and Organization, 11 (3): 209-220.

Zhang, Zhongyuan. 2006. "What is lived space.” Ephemera 6 (2): 219-223. 


\section{Appendices}

Figure 1: Road bowling, Lyre, County Cork, Ireland July $12^{\text {th }} 2015$

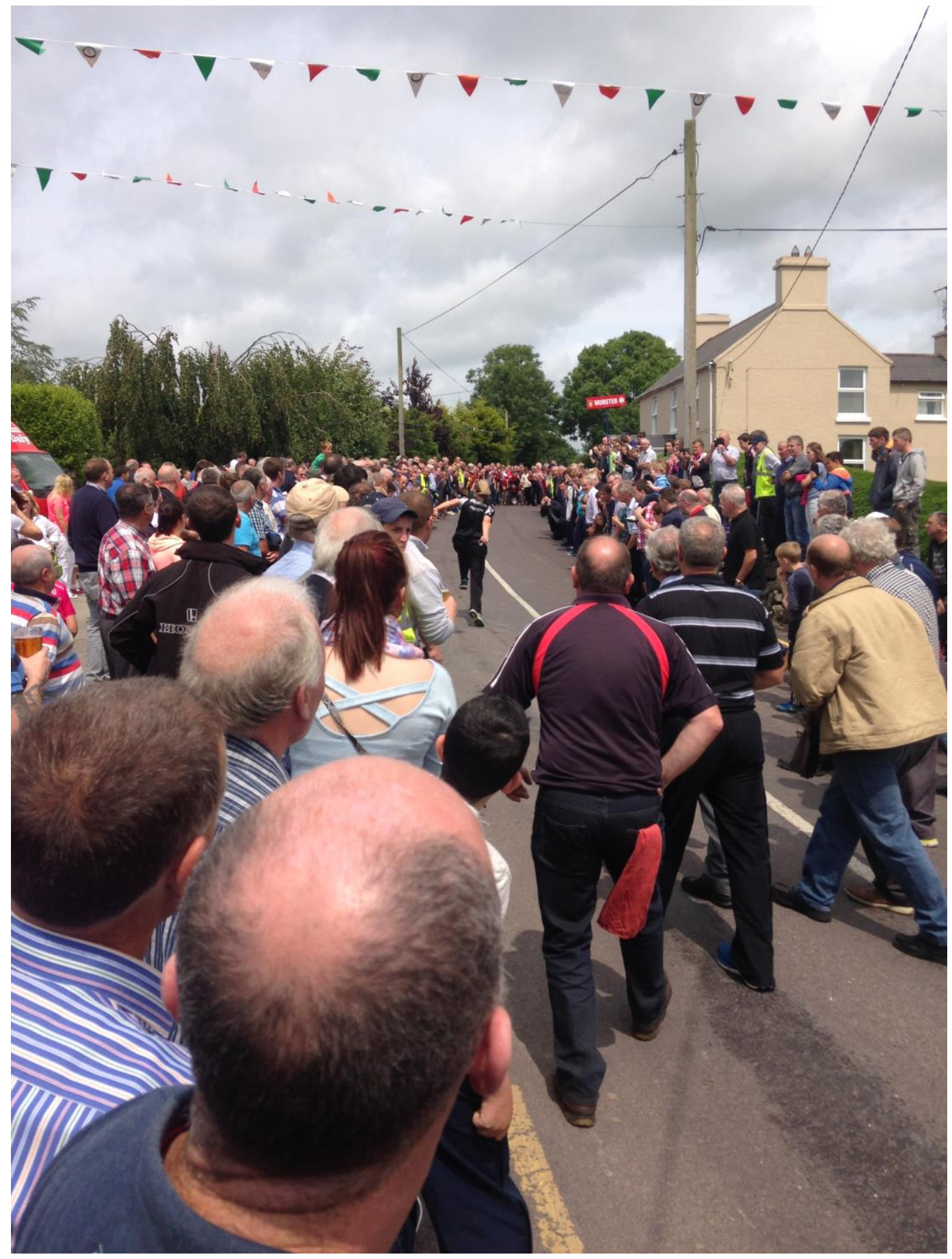


Table 1: Interviewee Profiles

\begin{tabular}{|c|c|c|c|}
\hline Name & Age & Occupation & Association to Road Bowling \\
\hline \multicolumn{4}{|c|}{ In-depth Interviewee Profiles } \\
\hline Michael & 32 & Factory worker & Bowling 20 years \\
\hline Alan & 28 & Farmer & Bowling 10 years \\
\hline James & 70 & Builder & $\begin{array}{l}\text { Former road bowler and road bowling } \\
\text { supporter for } 40+\text { years }\end{array}$ \\
\hline Seamus & 55 & $\begin{array}{l}\text { University } \\
\text { Lecturer }\end{array}$ & $\begin{array}{l}\text { Bowling 30+ years and former secretary of } \\
\text { Ból Chumann na hÉireann }\end{array}$ \\
\hline Ken & 38 & Security Worker & Bowling 5 years \\
\hline Denis & 36 & Builder & $\begin{array}{l}\text { Bowling } 24 \text { years, former All-Ireland } \\
\text { champion }\end{array}$ \\
\hline Jerimiah & 82 & Retired & $\begin{array}{l}\text { Former road bowler and supports for } \\
60+\text { years }\end{array}$ \\
\hline Liam & 37 & Carpenter & Bowling 5 years \\
\hline Sharon & 40 & Driving Instructor & $\begin{array}{l}\text { Bowling } 25 \text { years, former All-Ireland } \\
\text { champion }\end{array}$ \\
\hline Oísin & 24 & Student & Filmed a short documentary of the sport. \\
\hline \multicolumn{4}{|c|}{ Informal Interviewees referred to } \\
\hline Scott & 28 & Filmmaker & $\begin{array}{l}\text { None-commissioned to film road bowling } \\
\text { for a St.Patrick day advertisement for an } \\
\text { International Irish brand }\end{array}$ \\
\hline Peggy & 90 & Retired Farmer & $\begin{array}{l}\text { Has lived in the road bowling stronghold of } \\
\text { West Cork all her life, has five sons and two } \\
\text { grandsons who all at some point have played } \\
\text { road bowling. }\end{array}$ \\
\hline
\end{tabular}


Figure 2: "Man on the sop"- Person who directs which section of the road a road bowler should aim his/her throw with a piece of grass.

Source: Ból Chumann na hÉireann

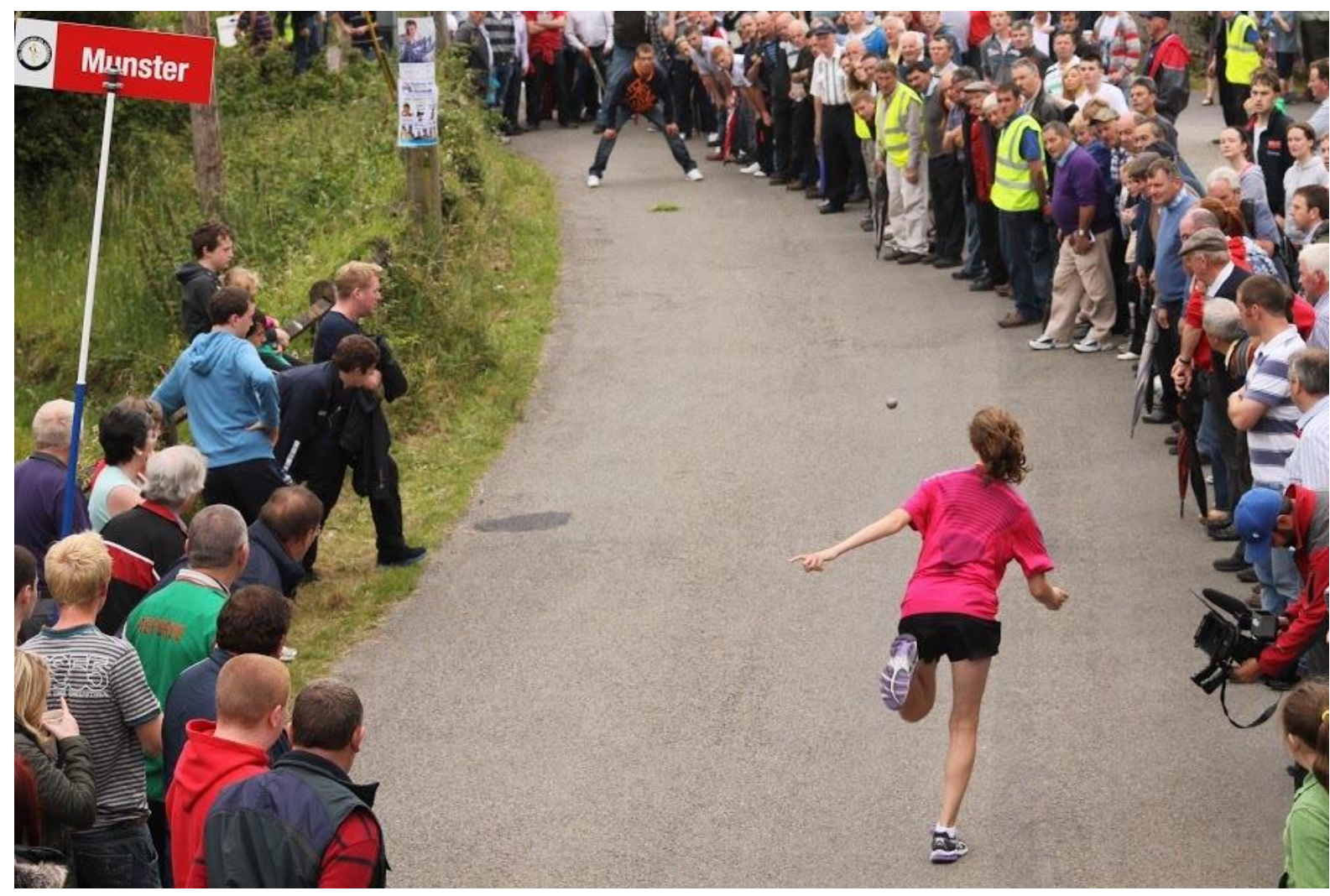


Figure 3: Road liner - Person who positions a road bowler at his/her throwing point Source: Ból Chumann na hÉireann

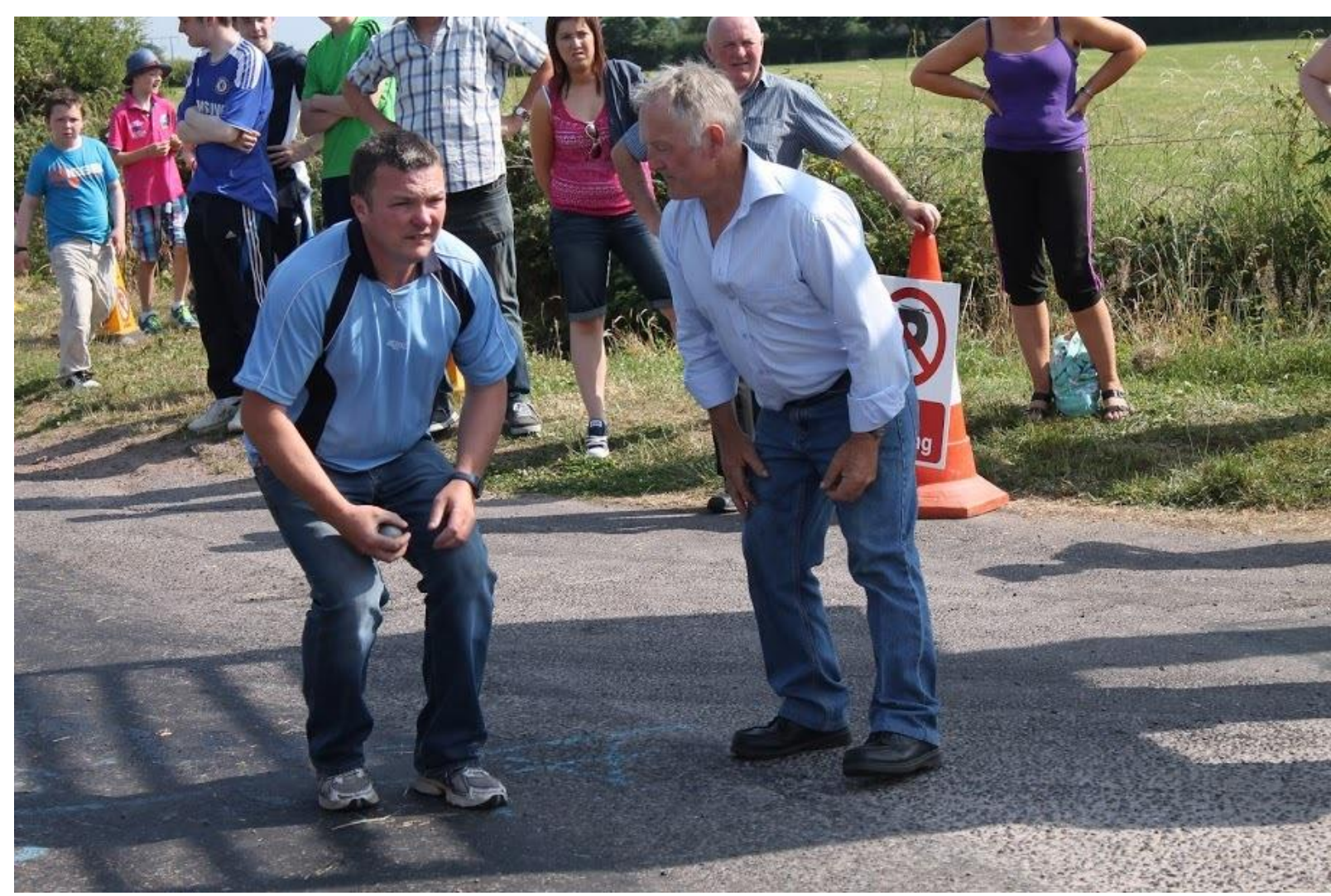


Figure 4: Collection of a stake by the first author during his time in the field.

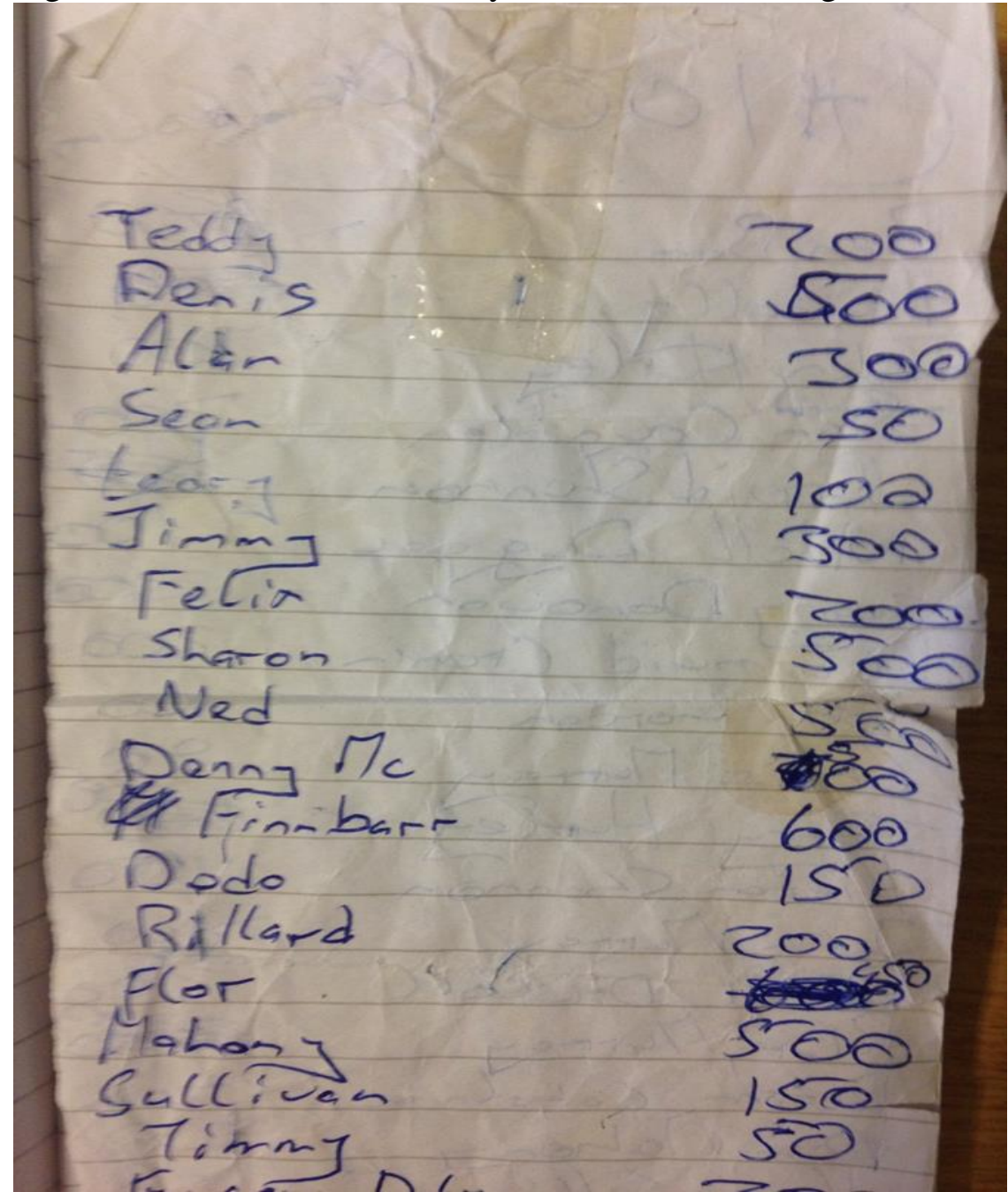


Figure 5: Court summons for the playing of road bowling in Tipperary 1856

Source: Fenor road bowling club

RRSH PETTY SEShiour Coute Recoeds 1856 (BRTTAN)

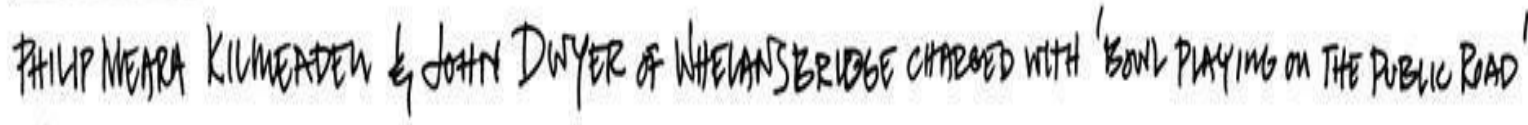

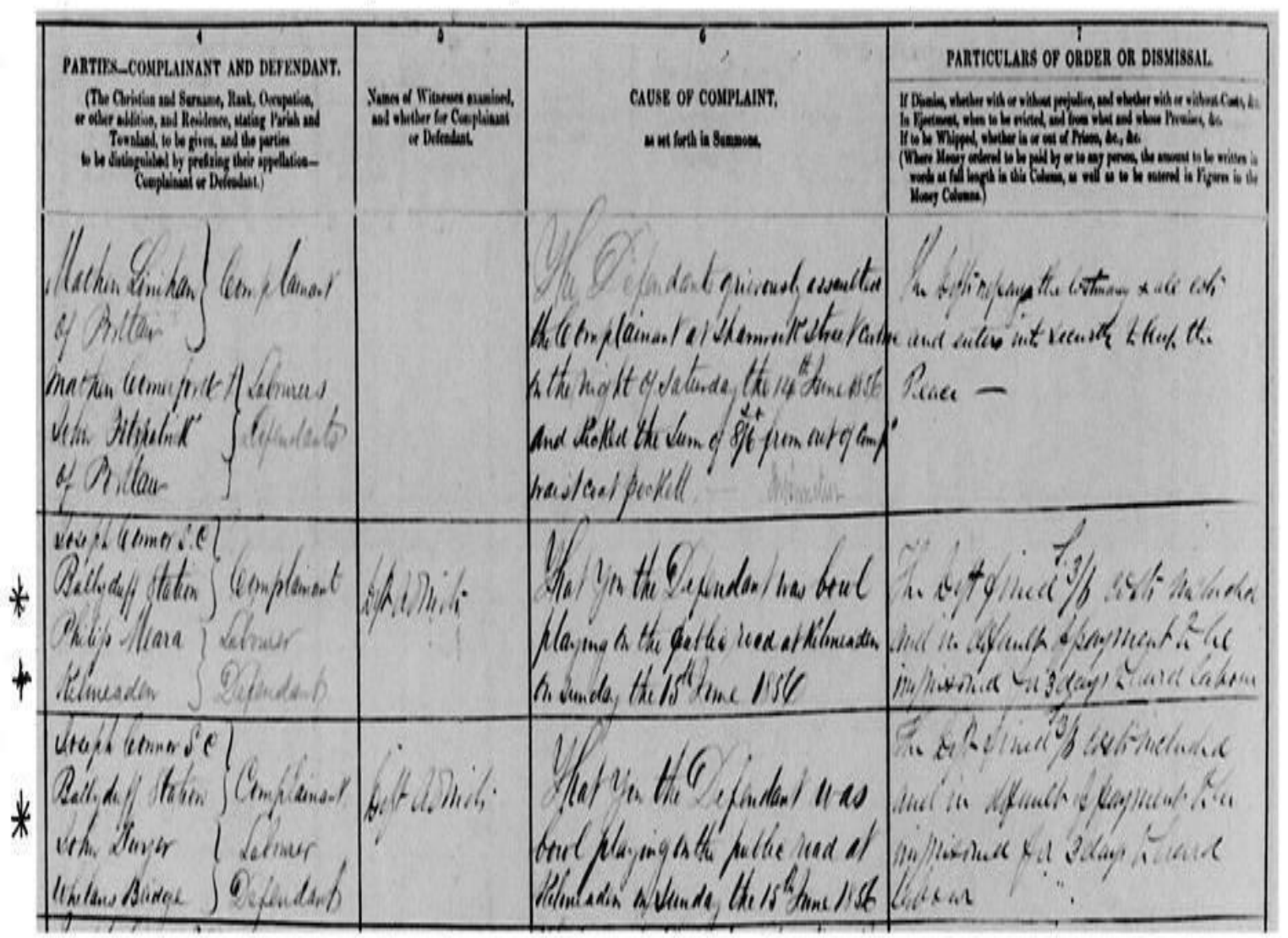

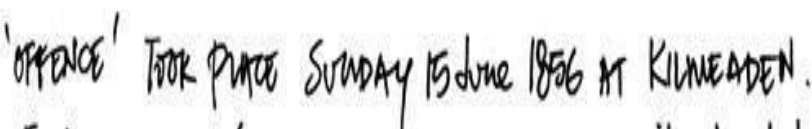

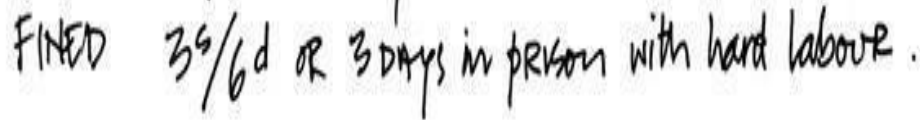


Figure 6: Illegal road bowling Drimoleague, Co. Cork, December 1915, Source: Skibbereen Eagle

Anyone reading the report of the last Drimolengue Petty Sossions will be struck with the number of young mon who were put to the expenso of a prosecution for indulging in the manls sport of bowling. One would think there aro many moro profitable channels into which constabulary activity might be diverted than in hunting down bowl-playora: To our mind, there is not a beitor way of spending a Sunday evening. Ovor and over again magistratea bavo expressed their sympethy with the game. But why un Heavon's name do theero same men fine the dofondants in a sum of one or two shillings? As they must inflet somo penalty, wouldn't a penny fino do as well? 